UDC $574 * 502.476$

\author{
E. MICHAELI ${ }^{1}$, prof., V. SOLAR ${ }^{1}$, prof., M. IVANOVA ${ }^{1}$, docent, J. VILCEK $^{1}$, prof., \\ A. LISNYAK ${ }^{2,3}$, docent \\ ${ }^{I}$ University of Presov in Presov, faculty of management, \\ Konštantínova st.15, 08001 Presov, Slovak Republic \\ ${ }^{2}$ Ukrainian Research Institute of Forestry and Forest Melioration named after G. M. Vysotsky, \\ Pushkinska st. 86, Kharkiv, 61024, Ukraine, \\ ${ }^{3}$ V.N. Karazin Kharkiv National University, ecological faculty, 6 Svobody Sq., 61077, Ukraine \\ e-mail:anlisnyak@gmail.com
}

\title{
ENVIRONMENTAL DIFFERENCES OF LAND CREATION IN TIME INTERVAL FOR DETERMINATION OF INDUSTRIAL INFLUENCE ON LANDSCAPE
}

The assessment of the spatial structure the land cover has great significance for the research of landscape especially from the aspect of the maintaining landscape ecological stability and the sustainable development as well as the landscape potential. At the same time it has an important role in identifying of impacts the industry on the landscape. The classes of land cover layers can be considered as the basis for other analyses of landscape. Purpose.: In the contribution we decided to compare the changes in landscape structure between the years 1958 - 2009 in territory of city Krompachy. Methods: field, analytical and mathematical. Results: For evaluating changes in the landscape structure we used topographic map from 1958 and orthophotomaps of the actual situation in 2009. The changes in the landscape structure were evaluated through GIS technologies in time horizon 1958 - 2009. Absolute and percentage differences in the land cover classes for the time horizon 1958 - 2009 are expressed by means of contingency tables transformation. The trends in the development classes of land cover are documented by the graph of the land cover classes on the second hierarchical level.

Key words: landscape structure, land cover assessments, landfill waste, Krompachy

Міхаелі Е. ${ }^{1}$, Солар В. ${ }^{1}$, Іванова М. ${ }^{1}$, Вілчек Й. ${ }^{1}$, Лісняк А. ${ }^{2,3}$

ЕКОЛОГІЧНІ ВІДМІННОСТІ ЗЕМЕЛЬНОГО ПОКРИВУ В ЧАСОВОМУ ІНТЕРВАЛІ ПРИ ВИЗНАЧЕННІ ВПЛИВУ ПРОМИСЛОВОСТІ НА ЛАНДШАФТИ

${ }^{1}$ Пряшівський університет у Пряшіві,

${ }^{2}$ Українский науково-дослідний інститут лісового господарства та агролісомеліораиії імені Г. М. Висоиького

${ }^{3}$ Харьковскій національний університет імені В.Н. Каразіна

Оцінка просторової структури рослинного покриву має велике значення для дослідження ландшафту, особливо з точки зору експлуатуючої ландшафтної екологічної стабільності та сталого розвитку, а також ландшафтного потенціалу. У той же час вона грає важливу роль у визначенні впливу промисловості на ландшафт. Класи шарів рослинного покриву можна розглянути як підставу для інших досліджень ландшафту. Мета: Порівнюються зміни в ландшафтній структурі між 1958 - 2009 роками на території міста Кромпачі. Методи: польовий, аналітичний та математичний. Результати: Для оцінки змін в ландшафтній структурі використано топографічну карту 1958 року і ортофотоплани фактичної ситуації 2009 року. При цьому, зміни в ландшафтній структурі були оцінені за допомогою ГІС-технологій в часовому інтервалі 1958 - 2009 pp. Абсолютні і процентні відмінності в класах земельного покриву для часового інтервалу 1958 - 2009 рр. виявлені за допомогою перетворювальних таблиць. Тенденції зміни грунтоворослинного покриву встановлені за допомогою графіка класів рослинного покриву для другого ієрархічного рівня.

Ключові слова: ландшафтна структура, оцінка земельної покриву, звалища, Кромпачі

Михаэли Е. ${ }^{1}$, Солар В. ${ }^{1}$, Иванова М. ${ }^{1}$, Вилчек Й. ${ }^{1}$, Лисняк А. ${ }^{2,3}$

ЭКОЛОГИЧЕСКИЕ ОТЛИЧИЯ ЗЕМЕЛЬНОГО ПОКРОВА ВО ВРЕМЕННОМ ИНТЕРВАЛЕ ПРИ ОПРЕДЕЛЕНИИ ВЛИЯНИЯ ПРОМЫШЛЕННОСТИ НА ЛАНДШАФТЫ

${ }^{I}$ Пряшевский университет в Пряшево, факультет менеджмена

${ }^{2}$ Украинский научно-исследовательский институт лесного хозяйства и агролесомелиорации

имени Г. Н. Высоикого

${ }_{3}^{3}$ Харьковский национальный университет им. В.Н. Каразина

Оценка пространственной структуры растительного покрова имеет большое значение для исследования ландшафта, особенно с точки зрения эксплуатирующей ландшафтной экологической стабильности и устойчивого развития, а также ландшафтного потенциала. В то же время она играет важную роль в определении воздействия промышленности на ландшафт. Классы слоёв растительного покрова можно

(C) Michaeli E., Solar V., Ivanova M., J. Vilcek, Lisnyak A., 2017

DOI: https://doi.org/10.26565/1992-4224-2017-28-12 
рассмотреть как основание для других исследований ландшафта. Цель: Сравниваются изменения в ландшафтной структуре между 1958 - 2009 годами на территории города Кромпачи. Методы: полевой, аналитический и математический. Результаты: Для оценки изменений в ландшафтной структуре использовано топографическую карту 1958 года и ортофотопланы фактической ситуации 2009 года. При этом, изменения в ландшафтной структуре были оценены с помощью ГИС-технологий во временном интервале 1958 - 2009 гг. Абсолютные и процентные различия в классах земельного покрова для временного интервала 1958 - 2009 гг. выявлены с помощью преобразовательных таблиц. Тенденции изменения почвенно-растительного покрова установлены с помощью графика классов растительного покрова для второго иерархического уровня.

Ключевые слова: ландшафтная структура, оценка земельного покрова, свалки, Кромпачи

\section{Introduction}

Today's landscape is the result of longterm human influence on the original natural landscape [16]. Physical states the landscape represent the classes of land cover which reflect of the natural-spatial aspects landscape and today's status of land use [4]. A good indicator for the assessment of the intensity of economic impact on landscape is the changes in the landscape structure. They represent a sequence of different states of physical nature that bind to a certain time horizon [2]. Geographic information systems through the methods multitemporal analysis allow evaluating the changes, dynamics and trends of development of the classes land cover in the landscape and as well the mutual comparison the map layers from different time horizons. The multitemporal analysis reflects the character of these changes and their intensity and direction and therefore has an importance in the study of current landscape $[3,5,6,7,10,12,13,15,17]$.

Researched territory. Studied area is located in the district Spišská Nová Ves on the boundary of two geomorphological units Hornádskakotlina (basin) and Volovskévrchy (mts.). The territory is a genetical, morphological and ecological diversity. The largest part nearly $90 \%$ lies in mountain landscape of Volovskévrchy (mts.) and only $10 \%$ in landscape of Hornádskakotlina (basin). Geological structure of the area is a varied. From the geological aspects the territory consists of the geologictectonic unit of Gemericum (Palaeozoic and upper Palaeozoic) on which lies spišskýpríkrov (nappe) (nappe of Triassic limestone and dolomite, [13]). In these formations are the bearings of siderite, hematite and bearing of uranium ores, as well as gypsum and anhydrite. Hornádskakotlina (basin) is younger and was created in the Tertiary (flysch sequences of Inner Carpathian Palaeogene the complex of rhythmically alternating layers of claystones and sandstones). Varied geological structure is reflected in the relief of the area. Varied geological struc- ture is reflected in the relief of the area. According Climatic regionalization of the Slovak Republic the territory belong to Cool region, Sub-region $\mathrm{C} 1$, which is moderately cool an average temperature in July is $12-16^{\circ} \mathrm{C}$ [12].

River network represents on the northern edge of the territory Hornád(river)andits tributaries. Soil cover is formed mostly of Dystric Cambisol. On the floodplain of Hornád and its tributaries there are Dystric Fluvisols and on uplands of Hornádskakotlina (basin) there are Albic-Dystric Luvisols. Majority part of mountain landscape is forested mainly by a spruce with an admixture a fir. Forests have undergone a significant transformation at the end of $18^{\text {th }}$ century and in first half of the $19^{\text {th }}$ century (ore mining and processing). Hornádskakotlina (basin) is deforested agricultural landscape. Researched territory is negatively influenced by mining activity and processing of especially iron and copper ores. The city Krompachy is old industrial locality and city and its surroundings were polluted many years mining and processing of iron ore and non-ferrous metals and in the last three decades before the year 1993 mainly copper and mercury. The main sources of pollutions were "Kovohuty Krompachy" (metallurgic production) and copper mines in Slovinky. The main elements of pollutions in air, water and soil were heavy metals (mercury, arsenic, lead, cadmium) and sulphur oxides, because the bearing ores are sulphides. In "Kovohuty Krompachy" the chimney of the factory is $200 \mathrm{~m}$ high, which allows the extension of emissions of $\mathrm{SO}_{2}$ and arsenic into the considerable distance. This was reflected in the surrounding of city where they were damaged ecosystems in forests. From the "Kovohuty Krompachy" in the past (to 1993) was emitted into the atmosphere 35 000 tons of emissions per year, which caused permanent damage of the territory $[1,8]$. Other forms of threat the landscape structure are the landfills of industrial waste $[9,13]$. 


\section{Material and research methods}

Today's landscape structure was identified a vectorization orthophotomaps from year 2009. Layers classes of land cover for year 1958 were acquired of georeferencing and vectorization of military topographic maps of scale 1: 25000. For identify classes of land cover was necessary to adapt in the details legend Corine Land Cover (CLC) which is used for the processing of data layers from whole Slovak territory [4] to take account of the size and specifics of researched area. Therefore we used the legend on the fourth level CLC which was processed for the needs of landscape research in a more detailed scale [3]. In the legend on fourth hierarchical level are also included some specific land cover classes required for mapping in the model territory, for example discontinuous area with predominantly multi-floor buildings without gardens, the area of landfills of industrial and municipal waste and vegetation alongside watercourses. The digitization of data is often associated with random errors. For this purpose we used software for control of topology in ArcMap application of ArcGIS 10. Evaluation changes we conducted by the layers loaded in software ArcGIS 10. Through a script we calculated of transformation of individual land cover classes in absolute terms.

\section{Results of researches}

To changes in the classes of land cover in investigated territory have taken place especially at the end of the $18^{\text {th }}$ century and the first half of the $19^{\text {th }}$ century in context of development of mining and metallurgy. Changes in classes of land cover in the time horizon 1958 - 2009 (Fig. 1, 2, Table 1) were reflected mainly in the classes of forests but from the aspect of generic composition. Compared to the original composition of forests were influenced mainly planting of spruce how fastgrowing wood plants. Original beech forests been felled on produce of charcoal and on the stiffener in mines in the past. The beech forests are preserved only on the small areal in the northern part of the territory. In year 1958 had the largest representation coniferous forests but their area was reduced into 2009 by 427.8 ha at the expense of mixed forests. Changes were also in the classes permanent grasslands mainly without scattered trees and shrubs (2.3.1.1). Of them were transformed 119.8 ha on coniferous forests with continuous canopy (3.1.2.1) and were extended also to expense of the natural worth (3.2.4.2) about 107 ha.

Soils of the researched area were contaminated by emissions from industrial manufacturing. In this context some aerials of the arable land (2.1.1.1) about the area of 63.5 ha were designed for grassing and 31.5 ha was transformed into class of the grasslands mostly without scattered trees and shrubs (2.3.1.1.). Another significant fact which influenced the overall character of the landscape structure was the building of the Ski Resort Plejsy (1.4.2.1) about 41.4 ha. In the classes of technicized and urbanized areas (1.1.2.1, 1.1.2.2, 1.2.1.1, 1.2.2.1, 1.2.2.2) for the 51 years occurred to substantial changes (increased about 40.5 ha). In the city was recorded increase of the builtup area along the watercourses, but also in their background facilities. The most significant increase occurred in the north-western part of cadastral territory of city along of the new road between the city and Ski Resort. On the basis of ore mining and metallurgy were created two new classes of land cover. Landfill the industrial waste and tailing pond. Landfill waste Halña occurs in the areal Kovohuty Krompachy and is located on the right bank of the Hornád (river) on the northern border of the built-up area. It contains solid waste lead, arsenic, cadmium, sludge from processing manganese, zinc, copper and sulphuric acid and liquid waste of cyanide and municipal waste (estimation of the volume of landfill is $760000 \mathrm{~m}^{3}$, size $12.6 \mathrm{ha}$ ). The tailing pond near Krompachy is in essence water work with the highest dike in the Slovak republic (dike is $114 \mathrm{~m}$ high). The tailing pond has $17 \mathrm{ha}$; volume of sludge is 4.8 million tonnes. It presents the rest after mining of copper ore and is an environmental threat for city Krompachy, located in the south-western part of the cadastral territory of the city in the valley on the slope. All this classes of land cover (wastes) occupy together an area of 29.6 ha (Fig. 1, 2, Table 1). 


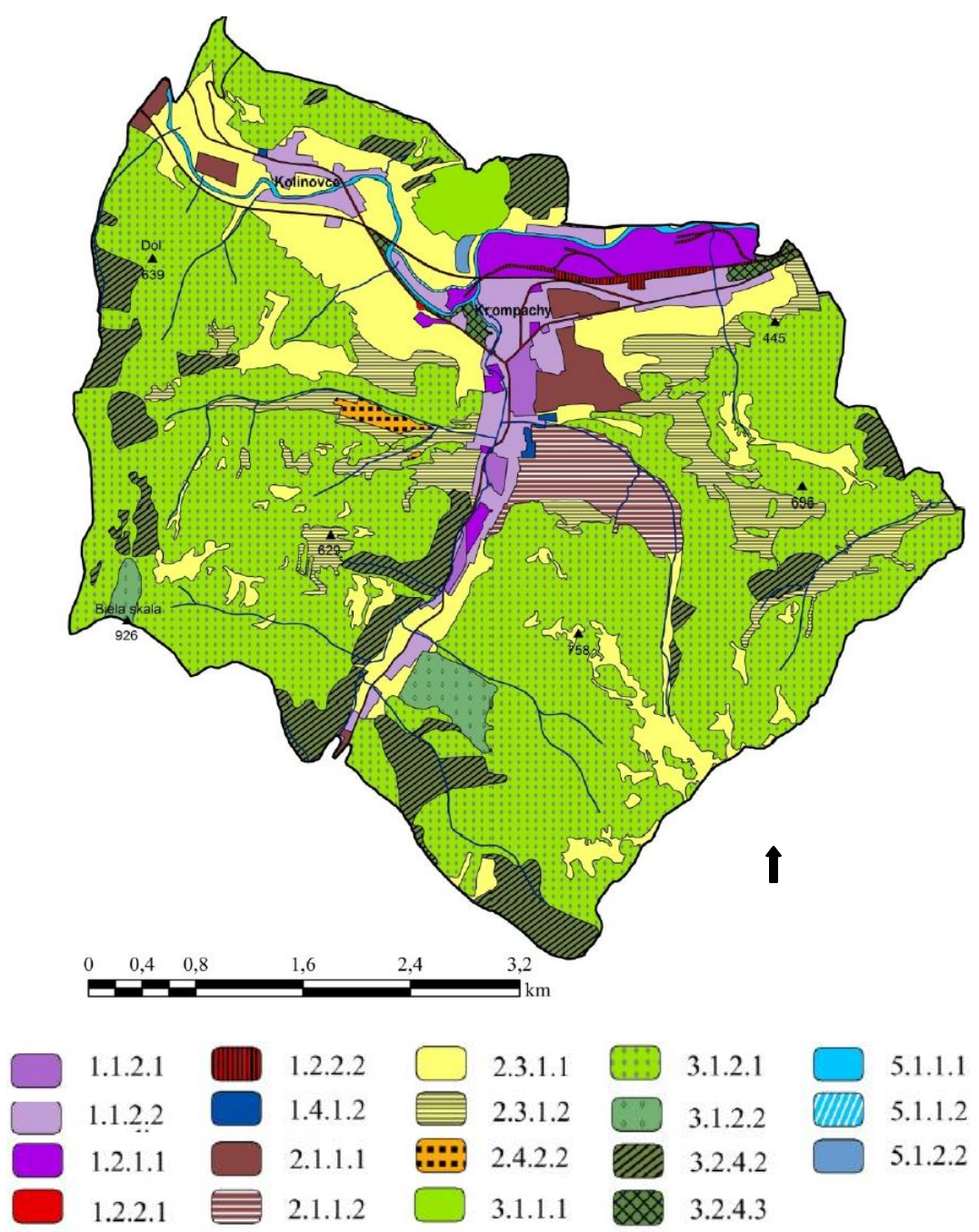

Fig.1 - Land cover in 1958

Table 1

Changes in land cover during the time period 1958-2009 (in ha)

\begin{tabular}{|c|c|c|c|c|c|c|c|c|c|c|c|c|c|c|c|c|c|c|c|c|c|c|c|c|c|c|}
\hline $\begin{array}{l}\text { Land } \\
\text { cover } \\
\text { classes }\end{array}$ & $\stackrel{\bar{̣}}{\stackrel{\Xi}{\leftrightarrows}}$ & $\stackrel{\text { Iี }}{\stackrel{3}{=}}$ & 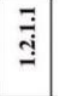 & ت্் & กี & $\stackrel{\dddot{3}}{\stackrel{3}{3}}$ & స்̃ & ت & 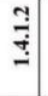 & ت்ָ & ב̇ & $\bar{c}$ & $\frac{\text { Tุ }}{3}$ & 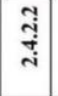 & $\underset{\vdots}{\doteqdot}$ & בְ & 导 & $\underset{\text { ले }}{\bar{m}}$ & $\frac{\bar{g}}{\dot{m}}$ & $\begin{array}{l}\overrightarrow{\dot{d}} \\
\dot{m}\end{array}$ & $\underset{\text { ç }}{\stackrel{3}{4}}$ & $\underset{\leftrightarrows}{\leftrightarrows}$ & $\stackrel{\text { İ }}{=}$ & ড় & 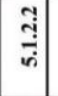 & 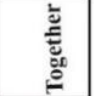 \\
\hline 1.1.2.1 & 16,6 & 0,1 & 0 & 0 & 0 & 0 & 0 & 0 & 0 & 0 & 0 & 0 & 0 & 0 & 0 & 0 & 0 & 0 & 0 & 0 & 0 & 0 & 0 & 0 & 0 & 16.7 \\
\hline 1.1.2.2 & 7,2 & 98.5 & 2,8 & 0 & 0 & 0 & 0 & 2,3 & 1,0 & 0 & 0 & 2.6 & 4,1 & 0,1 & 0 & 0 & 0,5 & 4.4 & 0,3 & 0,2 & 0,1 & 1.5 & 0 & 0 & 0 & 125,5 \\
\hline 1.2.1.1 & 0 & 0.4 & 52,3 & 0 & 0,8 & 0 & 11,3 & 0 & 0 & 0 & 0 & 1,1 & 0.2 & 0 & 0 & 0 & 0,6 & 0 & 0 & 0 & 0 & 0.3 & 0,1 & 0 & 0 & 67 \\
\hline 1.2.2.1 & 0 & 0 & 0 & \begin{tabular}{|l|}
10,7 \\
\end{tabular} & 0 & 0 & 0 & 0 & 0 & 0 & 0 & 0 & 0 & 0 & 0 & 0 & 0 & 0 & 0 & 0 & 0 & 0 & 0 & 0 & 0 & 10.7 \\
\hline 1.2.2.2 & 0 & 0 & 1,7 & 0 & 12,7 & 0 & 0,6 & 0 & 0 & 0 & 0 & 0 & 0 & 0 & 0 & 0 & 0,1 & 0 & 0 & 0 & 0 & 0 & 0 & 0 & 0 & 15,1 \\
\hline 1.4 .1 .2 & 0 & 0,2 & 0 & 0 & 0 & 0 & 0 & 0 & 2,5 & 0 & \begin{tabular}{l|l}
0 \\
\end{tabular} & 0 & 0 & 0 & 0 & 0 & 0 & 0 & 0 & 0 & 0 & 0 & 0 & 0 & 0 & 2.8 \\
\hline 2.1.1.1 & 0.9 & 3.4 & 3,4 & 0 & 0 & 0 & 0 & 0 & 0 & 0 & 3.2 & 31.5 & 0 & 0 & 0 & 1.6 & 0 & 0.5 & 0,2 & 0 & 0 & 0 & 0 & 0 & 0 & 44.7 \\
\hline 2.1 .1 .2 & 0 & 17,3 & 0 & 0 & 0 & 0 & 0 & 0 & 0,6 & 12,9 & 0 & 24,2 & 0 & 4,8 & 0 & 0 & 0 & 6,3 & 1,1 & 0,1 & 0 & 0 & 0 & 0 & 0 & 67,2 \\
\hline 2.3.1.1 & 0.4 & 23,9 & 3,8 & 0 & 0 & 0 & 0 & 0 & 0,4 & 19,7 & \begin{tabular}{l|l}
0,8 & 1 \\
\end{tabular} & 108,6 & 72,8 & 0 & 6,4 & 0,7 & 1,8 & 119.8 & 37,3 & 5,3 & 0 & 2.2 & 0,3 & 0,1 & 1,0 & 405,2 \\
\hline 2.3.1.2 & 1,0 & 3,4 & 0 & 0 & 0 & 0 & 0 & 0 & 0 & \begin{tabular}{|l|}
0 \\
\end{tabular} & \begin{tabular}{l|l}
0 \\
\end{tabular} & 27.6 & 44,5 & 12.8 & \begin{tabular}{|l|}
3,2 \\
\end{tabular} & 0 & 0 & 51,9 & 45.6 & 0 & 0,3 & 0 & 0 & 0 & 0 & 190.3 \\
\hline 2.4.2.2 & 0 & 0 & 0 & 0 & 0 & 0 & 0 & 0 & 0 & 0 & 0 & 0 & \begin{tabular}{l|l}
0 \\
\end{tabular} & 8.3 & 0 & 0 & 0 & 0.3 & 0 & 0 & 0 & 0 & 0 & 0 & 0 & 8.6 \\
\hline 3.1.1.1 & 0 & 0 & 0 & 0 & 0 & 0 & 0 & 0 & 0 & 0 & 0 & 0 & 0 & 0 & 18.2 & 0 & 0 & 6.8 & 1.8 & 5.1 & 0 & 0 & 0 & 0 & 0 & 31.9 \\
\hline 3.1 .2 .1 & 0 & 1.2 & 0 & 0 & 0 & 0.7 & 4.2 & 0 & 0 & 6.6 & 0 & 2.2 & 4.7 & 1.4 & 6.1 & 0 & $\begin{array}{lll}0 & 1\end{array}$ & 1003.5 & 427.8 & 13.7 & 0 & 0 & 0 & 0 & 0 & 1472.1 \\
\hline 3.1.2.2 & 0 & 1,5 & 0 & 0 & 0 & 0 & 0 & 0 & 0 & 0 & 0 & 0 & 7,6 & 0 & 0 & 0 & 0 & 27,3 & 0,1 & 0 & 0 & 0 & 0 & 0 & 0 & 36,4 \\
\hline 3.2 .4 .2 & 0 & 0,2 & 0 & 0 & 0 & 0,8 & 11,8 & 0 & 0 & 2,1 & 0 & 0 & 0,4 & 0 & 15,4 & 0 & 0 & 107 & 67 & 18,8 & 5,2 & 0 & 0 & 0 & 0 & 228.7 \\
\hline 3.2.4.3 & 0 & 1,5 & 1,5 & 0 & 0 & 0 & 1,2 & 0 & 0 & 0 & 0 & 1,1 & 0 & 0 & 0 & 0 & 1,1 & 0 & 0 & 0 & 5,2 & 0,3 & 0 & 0 & 0 & 11,9 \\
\hline 5.1.1.1 & 0 & 1,7 & 2,5 & 0 & 0 & 0 & 0.5 & 0 & 0 & 0 & 0.4 & 1.9 & 0 & 0 & 0,1 & 0 & 1,8 & 0 & 0 & 0 & 0.1 & 8.3 & 0 & 0 & 0 & 17,4 \\
\hline 5.1.1.2 & 0 & 0.6 & 0,2 & 0 & 0 & 0 & 0 & 0 & 0 & 0 & 0 & 0 & 0.4 & 0 & 0 & 0 & 0 & 0 & 0 & 0 & 0 & 0 & 0.3 & 0 & 0 & 1.4 \\
\hline 5.1.2.2 & 0 & 0 & 0 & 0 & 0 & 0 & 0 & 0 & 0 & 0 & 0 & 0 & 0 & \begin{tabular}{l|l}
0 \\
\end{tabular} & 0.1 & 0 & 0.2 & 0 & 0 & \begin{tabular}{l|l}
0 \\
\end{tabular} & 0 & 0 & 0 & 0 & 2.6 & 2.9 \\
\hline Together & 26,2 & 153,7 & 68,2 & \begin{tabular}{ll|}
10,7 \\
\end{tabular} & 13.5 & 1.5 & 29,6 & \begin{tabular}{l|l}
2,3 \\
\end{tabular} & 4,4 & 41,4 & \begin{tabular}{l|l}
4,3 & 2 \\
\end{tabular} & 200,7 & 134,7 & 27.3 & 49,4 & 2.3 & \begin{tabular}{l|l}
6 & \\
\end{tabular} & 1327,7 & \begin{tabular}{|l|l|}
581,2 \\
\end{tabular} & 43,2 & 10.9 & 12.8 & 0.7 & 0,2 & 3.6 & 2756,5 \\
\hline Explanatior & & $2.1 \mathrm{dis}$ & scontin & huous b & & & 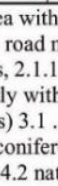 & 工 & ti-stor & 工 & . & igs mos & stly witl & & garden & & $.2 .2 \mathrm{~d}$ & discontin & nuous are & rea wit & th fam & iily hot & & stly w & vith ga & $\begin{array}{l}\text { ardens, } \\
1.4 .1 .1 \\
\text { ered (line }\end{array}$ \\
\hline
\end{tabular}




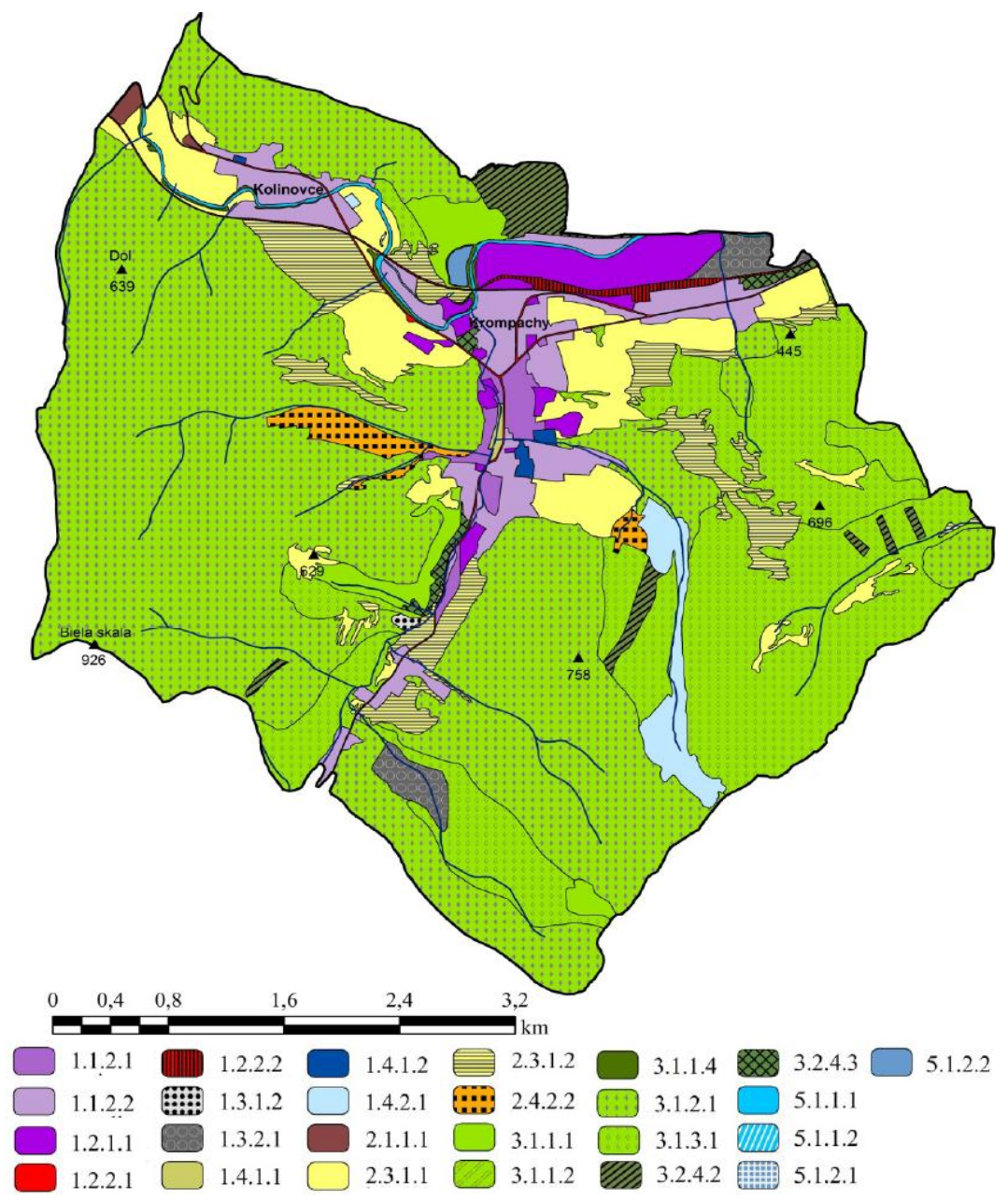

Fig. 2 - Land cover in 2009

\section{Discussions and conclusion}

Researched territory is located in the area of Middle Spiš. The territory belongs to the fifth class the quality of environment Slovak Republic. Long-term effects of extreme pollution from production of metallurgical plants, electrical engineering industry and mining of ores have caused significant changes in classes of land cover. The time horizon 1958 - 2009 from the aspect of the changes of the land cover we consider as a relatively short period but nevertheless the changes in classes of land cover in that short time period also are significant. At the mining and processing of ores were created new classes of the land cover belonging to the groups of the artificial surfaces for example: flotation tailing pond, landfills of the industrial and dangerous waste etc. All of them are the environmental loads. The most serious problem is that the negative impacts of industrial activities are reflected in agriculture. Due to extreme contamination of agricultural soils by heavy metals gradually deleted from agricultural land fund and the crop production had been banned. In 2009 the arable land occupying only 4 ha today in essence not anymore (Fig. 1, 2, Table 1). The class of permanent grasslands was gradually transformed into the forest communities in favour to class the coniferous forests with continuous canopy. The changes were also reflected into functional structure of the landscape mainly in the context of economic transformation in year 1999 when the occurred attenuation of Metallurgy and of ore mining. The environmental damage of the territory persists until today and territory is not suitable for input of investors, therefore the development of the region in the near future is questionable. Current status of environment the territory will be affected a future of development.

Acknowledgment : This contribution was originated from the financial support of the "VEGA" Grant agency of the Ministry of Education, Science, Research and Sports of Slovak Republic from the project VEGA No. 1/0159/15, VEGA No. 1/0116/16 and project APVV-150406 Agency to support research and development. 


\section{References}

1. Čech. V., Michaeli E., Krokusová J., Ivanová M. (2015). Contamination of Selected Components of Environment in the Middle Spiš Region (Slovak Republic). Geobalcanica. Conference Procedings. 43 - 50. [in Slovak].

2. Feranec J. (1997). Analýza zmien krajiny aplikáciou údajov dial'kového prieskumu Zeme. Geographia Slovaca. № 13. Bratislava: GÚ SAV. 64. - ISSN 1210-3519. [in Slovak].

3. Feranec J., Ot’ahel' J. (1999). Mapovanie krajinnej pokrývky metódou CORINE v mierke 1:50 000: návrh legendy pre krajiny programu Phare. Geografický časopis. 51( 1). 19-44. [in Slovak].

4. Feranec J. , Ot’ahel' J. (2001). Krajinná pokrývka Slovenska.Bratislava: Veda. 124. - ISBN 80-224-0663-5. [in Slovak].

5. Franklin J. ,Forman R.(1987). Creating landscape patterns by forest cutting: ecological consequences and principles. Landscape Ecology. 1. 5-18. [in English].

6. Gardner R. (1987). Neutral models for analysis of broad-scale landscape patterns. Landscape Ecology. 1. 19-28. [in English].

7. Hruška M. Vývoj zmien krajinnej pokrývky a funkčného využívaní územia katastrálnych území obcí Krompachy a Kolinovce. Prešov: FHPV PU. 107. [in Slovak].

8. Ivanová M. (2013). Zmeny krajinnej pokrývky zázemia Zeplnínskej šíravy v rokoch 1956 - 2009.Geografické práce. 15. 233. - ISBN978-80-555-0728-6. [in Slovak].

9. Ivanová M., Michaeli E., Boltižiar M.(2013). Analýza zmien priestorovej štruktúry krajinnej pokrývky územia severne od vodnej nádrže Zemplínska šírava . Geografický časopis. 65( 3), 235 - 250. [in Slovak].

10. Jaeger J. (2000). Landscape division, splitting index, and effective mesh size: new measures of landscape fragmentation . Landscape Ecology. 15. 115-130. [in English].

11. Krokusová J. (2013). Vplyv priemyselného odkaliska Halňa na štruktúru krajiny mesta Krompachy a možnosti jeho rekultivácie. Acta Facultatis Studiorum Humanitatis et Naturae Universitatis Prešoviensis, Folia Geographica. roč. 55. 2013, č. 21, p. 48-66. [in Slovak].

12. Lapin M. (2002). Climatic Regions. Landscape Atlas of the Slovak Republic, 2002, s. 95 . Map of Climatic Regions No 27, p. 95 in Landscape Atlas of the Slovak Republic, Ministry of Environment of the Slovak Republic. [in English].

13. Mahel’ M. Geologická stavba československých Karpát. Paeoalpínske jednotky. № 1. Bratislava: VEDA, p. 35 - 41. [in Slovak].

14. Mazúr E. Geomorphological units. / E. Mazúr, M Lukniš, In: Ed. Mazúr, E (ed.) . Atlas of the Slovak Socialists Republic. Bratislava. SAV a SÚGK, Map No. 16, p. 54 - 55. [in Slovak].

15. Michaeli E., Ivanová M., Koco Š. (2015). The evaluation of anthropogenic impact on the ecological stability of landscape . Journal of Environmental Biology, 36 ( SI). 1- 7. - ISSN 0254-8704. [in English].

16. Žigrai F. (2000). Dimenzie a znaky kultúrnej krajiny. Životné prostredie. 34(5), p. 229-233. [in Slovak].

17. Lisnyak A., Michaeli E., Boltiziar M., Vilcek J., Solar V. (2014). The landfill of industrial waste from nickel production and its impact on the landscape (case study from sered in Slovak republic). Man and the environment. Issues of neoecology. . 3-4. 99-104. - ISSN 1992-4224. [in English].

Надійшла до редколегії 06.09.2017 